\title{
REPRESENTASI HARAPAN DAN HOPELESSNESS DALAM VIDEO CLIP BTS “INTERLUDE: SHADOW" (KAJIAN SEMIOTIKA ROLAND BARTHES)
}

\author{
Ratu Nadya Wahyuningratna ${ }^{1}$ \\ Irpan Ripa'i Sutowo² \\ 1,2 Program Studi IImu Komunikasi, Fakultas IImu Sosial dan IImu Politik \\ Universitas Pembangunan Nasonal Veteran Jakarta
}

Naskah diterima tanggal 04-03-2020, direvisi tanggal 12-06-2020, disetujui tanggal 21-06-2020

\begin{abstract}
Abstrak. Tanpa harapan, seseorang seolah tidak memiliki tujuan dalam hidupnya. Namun kadang manusia tak hanya memiliki harapan yang sifatnya positif dalam hidupnya, tetapi juga memiliki keputusasaan atau hopelessness di saat sesuatu tidak berjalan sesuai keinginannya. Kedua perasaan ini memungkinkan timbulnya di saat-saat tertentu, namu tidak semua orang mampu membaginya dengan orang lain. Berbeda dengan para musisi, mereka yang biasa menciptakan lagu, seringkali diberi kebebasan untuk mencurahkan perasaannya melalui lagulagu yang dibuatnya. Seperti halnya dengan boyband asal Korea Selatan, BTS, mereka diberi kebebasan oleh agensi yang menaunginya untuk mencurahkan perasaan mereka melalui lagulagu yang mereka ciptakan sendiri. Melalui lagu, mereka merasa bisa mengomunikasikan apa yang sedang mereka pikirkan dan rasakan kepada khalayak, terutama fans mereka (ARMY). Kejujuran yang mereka sampaikan lewat lirik lagu, rasa cinta mereka terhadap fans, bahkan harapan dan keputusasaan bisa dirasakan langsung oleh semua orang. Tak terkecuali lagu "Interlude: Shadow", dari lirik dan video clip nya sendiri kita bisa menemukan isyarat harapan dan hopelessness di dalamnya. Karena itu penulis tertarik untuk mencari tahu lebih dalam representasi harapan dan hopelessness dari video clip "Interlude: Shadow" ini menggunakan Semiotika Roland Barthes.
\end{abstract}

Kata kunci: Representasi, harapan, hopelessness, BTS, Semiotika Roland Barthes

\begin{abstract}
Without hope, someone seems to have no purpose in life. But sometimes humans not only have positive expectations in life, but also have hopelessness when things don't go their way. Both of these feelings can arise at certain times, but not everyone is able to share them with others. In contrast to musicians, those who are used to creating songs are often given the freedom to express their feelings through the songs they make. Like the South Korean boy band, BTS, they were given freedom by the agency that sheltered them to express their feelings through songs that they created themselves. Through songs, they feel they can communicate what they are thinking and feeling to the audience, especially their fans (ARMY). The honesty that they convey through song lyrics, their love for fans, even hope and despair can be felt directly by everyone. No exception to the song "Interlude: Shadow", from the lyrics and the video clip itself we can find signs of hope and hopelessness in it. Therefore, the author is interested in finding out more about the representation of hope and hopelessness from the video clip "Interlude: Shadow" using Semiotics Roland Barthes.
\end{abstract}

Keywords: Representation, hope, hopelessness, BTS, Roland Barthes Semiotic. 


\section{PENDAHULUAN}

\section{A. Latar Belakang Masalah}

Setiap manusia memiliki harapan dalam hidupnya, dengan tujuan untuk membuat hidupnya menjadi lebih baik. Pengertian dari harapan itu sendiri adalah keyakinan individu tentang rencana sukses yang dapat dihasilkan untuk mencapai tujuan. Harapan memungkinkan seseorang untuk mengatasi situasi krisis dengan mengharapkan hasil yang positif (Hidayat, 2016, hal. 1). Harapan merupakan keinginan akan sesuatu supaya bisa terwujud, berbeda dengan cita-cita, harapan tidak mengenal batas waktu dan dan belum tentu dibarengi dengan tindakan nyata,

Namun kadang manusia tak hanya memiliki harapan yang sifatnya positif dalam hidupnya, tetapi juga memiliki keputusasaan atau hopelessness di saat sesuatu tidak berjalan sesuai keinginannya. Adanya perbedaan kondisi individu dalam menghadapi dan menyelesaikan masalah, persoalan, tantangan, serta rintangan dalam hidupnya serta perilaku yang ditunjukkan yang berbeda pula, diketahui ada beberapa individu tertentu yang berputus asa, atau sedang mengalami hopelessness. Hopelessness diterjemahkan sebagai keputusasaan diri yang menyebabkan ketidakberdayaan dan hilangnya harapan dan cita-cita (Melinda \& Khusumadewi, 2017, hal. 53).

Tak terkecuali bagi seorang musisi, salah satu cara menuangkan pikiran dan emosi mereka adalah melalui lagu. Mereka bisa menceritakan harapan, cita-cita, kesedihan, kebahagiaan dan bahkan keputusasaan lewat lirik lagu. Hal inilah yang juga dilakukan oleh grup band asal Korea Selatan, BTS, grup yang diwangi oleh RM, Suga, Jin, J-Hope, Jimin, V dan Jungkook ini memang dikenal sebagai grup band yang menulis dan memproduseri sendiri lagu mereka. Berbeda dengan kebanyak grup band K-Pop lain yang kebanyakan mengusung tema jatuh cinta, patah hati atau bersenang-senang (berpesta), grup band asuhan Big Hit Entertainment ini lebih memilih menulis lagu dengan gaya mereka sendiri. Oleh sang produser utama, Bang Sihyuk, para anggota BTS diberi kebebasan untuk menciptakan lagu dengan tema yang mereka inginkan. Dengan kemampuan menulis lirik dan memproduseri lagu mereka sendiri, para anggota BTS, terutama RM, Suga dan J-Hope berusaha untuk bisa menuangkan isi pikiran mereka melalui lagu.

Kemampuan menciptakan lagu dan menulis lirik yang erat dengan kehidupan sehari-hari terutama kehidupan remaja, menjadikan mereka sebagai panutan yang memberi dampak positif pada para penggemarnya. Dilansir dari Wowkeren.com, Menurut survei yang dilakukan oleh Embrain Trend Monitor, mayoritas tetua Korea Selatan yakin bahwa RM dan kawan-kawan memiliki dampak positif terhadap generasi muda. Survei tersebut melakukan penelitian dengan lebih dari 1.000 orang berusia antara 16-64 tahun. 64,2 persen responden setuju bahwa BTS memiliki pengaruh positif pada kaum muda, dengan 78,3 persen orang di usia 60 -an yang setuju. Selain itu, 77,4 persen juga setuju bahwa BTS adalah pengaruh positif, 70 persen di usia 40-an setuju, 64,5 persen di usia 30 -an, 50,5 persen di usia 20 -an, dan 38,2 persen sisanya adalah remaja.

Bagi mereka yang suka mendengarkan musik BTS, banyak yang setuju bahwa alasan terbesar adalah karena musik mereka sangat membuat ketagihan (44,7 persen). Reaksi kedua (dengan jumlah suara sama) adalah karena musik mereka memiliki kemampuan untuk menghibur pemuda dan memberi mereka semangat (25 persen). Beberapa juga mengatakan mereka suka musik BTS karena pesan yang bermakna dalam lagu (23 persen) (wowkeren, 2019, para. 1-4).

Tak hanya dari lirik lagu dan pesan yang ingin mereka sampaikan dalam musik mereka saja yang berdampak positif, namun juga dari apa yang telah mereka lakukan demi membuat sebuah perubahan. Dilansir dari Communication.binus.co.id, Ketika sudah mendunia, kecenderungan para artis langsung terkena skandal yang dapat menjatuhkan mereka. Berbeda dengan BTS, penghasilan mereka didonasikan kepada orang-orang bahkan hewan yang tidak beruntung. Salah satu anggota mereka, Jin, baru saja memberikan sumbangan untuk hewanhewan terlantar ke Korean Animal Welfare Association. Mereka juga menjadi donator untuk 
korban Ferry Sewol dengan menyumbang 100 juta. Tindakan tersebut menunjukan kerendahan hati (Kevin, 2019, para. 7).

Tak berhenti sampai di situ, BTS juga resmi menjadi salah satu Brand Ambassador UNICEF pada tahun 2017 dengan menggalakkan kampanye "Love Myself" yaitu mengajak para anak-anak dan remaja untuk mencegah perilaku bullying dan mereka yang menjadi korban untuk berani menyuarakan perasaan mereka. Dengan mengeluarkan merchandise resmi dan menyumbangkan sebagian dari penjualan album mereka, terkumpulah 1,4 juta dollar dana untuk disumbangkan. Hal ini membuktikan dampak positif mereka yang menyebar ke seluruh dunia (Herman, 2018, para. 2).

Lagu-lagu mereka yang berjudul Dope, 21th Century Girl, Not Today, Love Myself dan masih banyak lagi memang dianggap memiliki lirik yang catchy dan bermakna positif bagi pendengarnya. Dengan tujuan memberikan harapan dan keinginan untuk mencintai diri sendiri, mereka mengajak para penggemarnya untuk memandang kehidupan secara positif, menghargai diri sendiri, orang lain dan tidak takut untuk gagal.

Namun di tengah-tengah kepopuleran mereka yang terus menanjak, sebagai manusia biasa pastilah mereka pernah mengalami masa-masa sulit hingga depresi. Pada pidato penghargaan music M-Net Asia Music Awards di akhir tahun 2018 silam, salah satu anggotanya Jin, pernah blak-blakan mengungkapkan bahwa ia sempat ingin menyerah menjalani hidup sebagai seorang idola dan menginginkan pembubaran grup di awal tahun tersebut. Namun untungnya anggota yang lain terus menguatkannya dan memberikan gambaran bahwa masa depan mereka masih panjang, terbukti dengan banyaknya prestasi yang mereka dapatkan dari ranah internasional.

Kesulitan dan keputusasaan yang timbul di tengah harapan mereka sebagai musisi, dituangkan dengan apik melalui berbagai lagu ciptaan mereka sendiri. sebut saja Cypher part 3, Mic Drop, The Truth Untold, Save Me dan masih banyak lagi. Dalam lagu -lagunya mereka menceritakan bagaimana haters selalu ingin menjatuhkan mereka hingga perasaan mereka yang kadang berubah menjadi putus asa.

Salah satu lagu BTS yang mengisyaratkan harapan sekaligus keputusasaan adalah Interlude: Shadow. Lagu ini merupakan salah satu track dari album terbaru mereka Map of the Soul: 7 yang dirilis 21 Februri 2020. Lagu trailer atau yang lebih dikenal sebagai lagu "pembuka" ini diproduseri dan dinyanyikan sendiri oleh salah satu anggota mereka yaitu Suga. Video clip yang rilis di platform Youtube pada tanggal 9 Januari 2020 ini sangat memperlihatkan harapan dan keputusasaan yang dirasakan oleh sang pencipta lagu dari segi visual dan lirik.

Dengan visual yang menarik dan makna lirik yang mendalam, penulis tertarik untuk menelaan secara lebih jauh bagaimana kedua aspek ini merepresentasikan harapan dan hopelessness melalui kajian semiotika Roland Barthes. Semiotika Roland Barthes mengembangkan dua tingkatan pertandaan (staggered systems) yang memungkinkan untuk dihasilkannya maknayang bertigkat-tingkat, yaitu denotasi dan konotasi (Kodri, 2016, hal. 54).

Selain itu, Barthes juga melihat makna lebih dalam tingkatnya, tetapi lebih bersifat konvensional yaitu makna-makna yang berkaitan dengan mitos. Mitos dalam pemahaman semiotika Roland Barthes adalah pengkodean makna dan nilai-nilai sosial sebagai sesuatu yang dianggap alamiah atau cerita yang digunakan suatu kebudayaan untuk menjelaskan atau memahami beberapa aspek dari realitas atau alam (Kodri, 2016, hal. 54).

B. Rumusan Masalah

Dari latar belakang tersebut penulis ingin meneliti bagaimana harapan dan hopelessness direpresentasikan dalam Video Clip BTS berjudul "Interlude: Shadow" dari segi visual dan lirik yang ditampilkan menggunaka semiotika Roland Barthes. 


\section{METODE PENELITIAN}

Penelitian ini dilakukan dengan pendekatan kualitatif dengan metode analisis Semiotika Roland Barthes. Seorang ahli semiotika, Roland Barthes melibatkan keberadaan mitos dalam model semiotika yang dikembangkannya. Barthes merumuskan suatu teori tentang mitos yang mendasari tulisannya dalam Mythologie. Barthes mengungkapkan bahwa saat ini mitos adalah sebuah pesan-bukan konsep, gagasan, ataupun objek (Gora, 2016, hal. 165). Penggunaan metode analisis semiotika Roland Barthes digunakan oleh peneliti untuk mengetahui secara detail representasi harapan dan hopelessness direpresentasikan dalam Video Clip BTS berjudul "Interlude: Shadow", di mana proses pembentukan makna oleh semiotika bersifat intensional dan memiliki motivasi.

\section{HASIL DAN PEMBAHASAN}

\section{A. BTS dan Video Clip "Interlude: Shadow"}

BTS, akronim dari Bangtan Sonyeondan atau "Beyond the Scene", adalah boyband Korea Selatan yang menangkap hati jutaan penggemar di seluruh dunia. Anggota BTS adalah RM, Jin, SUGA, J-Hope, Jimin, V dan Jung Kook. Mendapatkan pengakuan dari musik mereka yang otentik, yang diproduksi sendiri dan penampilan terbaik dengan cara mereka berinteraksi dengan penggemar mereka, band ini sedang dalam perjalanan untuk menjadi ikon global sejak mereka debut pada Juni 2013. Sementara memberikan pengaruh positif melalui kegiatan seperti kampanye LOVE MYSELF dan pidato 'Speak Yourself' PBB, BTS telah memobilisasi jutaan penggemar di seluruh dunia (bernama ARMY), menduduki puncak tangga lagu musik terkemuka, menjual tur di seluruh dunia termasuk stadion dan telah diakui dengan berbagai penghargaan bergengsi seperti Billboard Music Awards dan American Music Awards (Bighit, para. 1).

BTS sudah meliris mini album dan full album dengan total 16 albums dari awal debut mereka 13 Juni 2013 (hingga awal 2020). Album teranyar mereka "Map of The Soul: 7" yang rilis 21 Februari 2020 mencetak rekor dengan penjualan 4 juta kopi sejak pre-order dibuka pada bulan Januari 2020. Angka empat juta itu naik secara nyata dari waktu yang singkat sebelumnya, yang menunjukkan bahwa sementara jutaan orang mungkin bergegas memesan, masih ada banyak orang yang tertarik untuk melakukannya. Big Hit Entertainment, label rekaman BTS, mengungkapkan bahwa antara 9 Januari (ketika pre-order dibuka) dan 15 Januari, album band superstar K-pop ini dibeli 3,42 juta copy (McIntyre, 2020, para. 4).

BTS merilis video clip Comeback Trailer 'Interlude: Shadow' sebagai track pembuka dari album "Map of the Soul:7" ini pada 9 Januari 2020 pukul 22.00 WIB. Dan sebulan setelah dirilis, video clip ini menyentuh angka 54 juta lebih penayangan dan 5,1 juta like di Youtube. Lalu hampir sebulan kemudian pada 2 Februari 2020 pukul 22.00 WIB, BTS kembali merilis video clip Comeback trailer "Outro: Ego" yang sudah ditonton lebih dari 24 juta penayangan setelah Sembilan hari dirilis. Kedua lagu "pembuka" dari album ini memiliki tema yang sangat berbeda. Interlude: Shadow memperlihatkan visualisasi, melodi dan lirik yang lebih "dark" sedangkan Outro: Ego terlihat dan terdengar lebih "fun" dan "bright".

\section{B. Analisis Penelitian}

Penulis akan mengkaji beberapa scene dari video clip BTS "Interlude: Shadow" yang diunggah oleh akun Youtube Bighit Labels (akun resmi Bighit Entertainment Korea Selatan) ini dan menelaah menggunakan Semiotika Roland Barthes untuk mencari tahu representasi harapan dan hopelessness dari segi visual dan lirik (yang ditranslate ke dalam Bahasa inggris). 


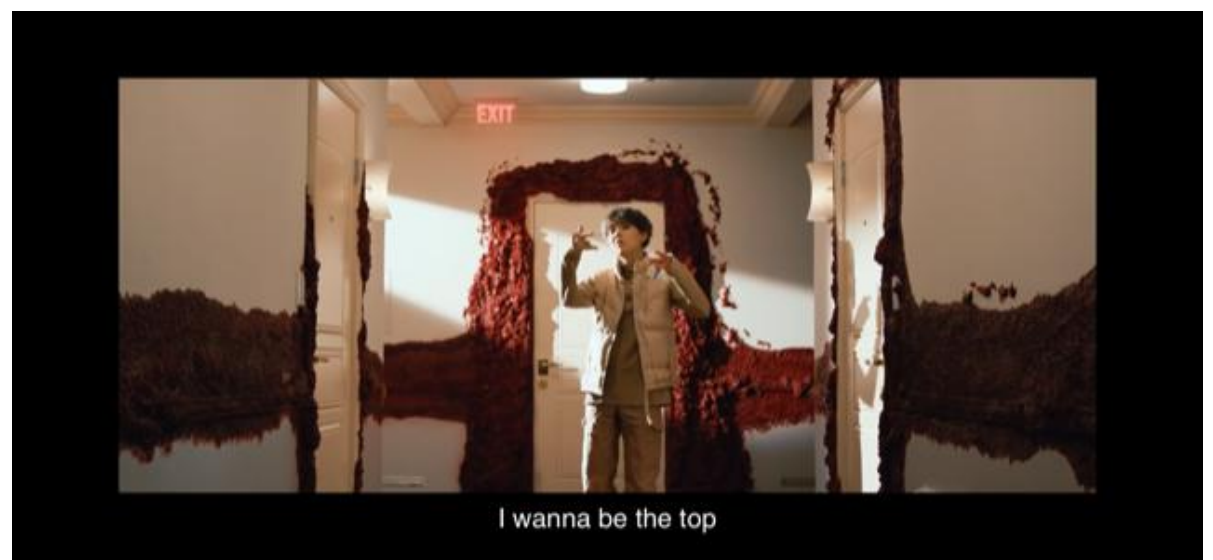

Gambar 1. Scene 1

Sumber: (akun Youtube Bighit Labels, 2020)

(Shoot: Long Shot)

Suga: "I wanna be the top"

Makna denotasi: Suga menyanyilan lirik "I wanna be the top" di depan ruangan dengan banyak jamur/lumut yang menempel.

Makna Konotasi: Suga yang merupakan seorang penyanyi rap menyanyikan lirik "I wanna be the top" yang mengisyaratkan bahwa ia mempunyai harapan untuk menjadi yang teratas, menjadi yang terhebat di pekerjaannya dan dari orang-orang sekitarnya. Namun di balik harapannya yang tinggi itu, ia berada dalam lingkungan yang toxic ditandai dengan banyaknya lumut atau jamur di dinding sekitarnya.

Mitos: Manusia memiliki harapan untuk menjadi yang tebaik, di lingkungan tempatnya berada. Tak terkecuali sang rapper Suga yang ingin menjadi idola teratas walau di lingkungannya yang terkadang tidak mendukung dan "tidak sehat". Makna dari jamur di dinding itu sendiri adalah kondisi di mana lingkungan tersebut lembab dan kurang layak. Beberapa jenis jamur dalam ruangan mampu menghasilkan racun yang sangat ampuh (mikotoksin) yang larut dalam lemak dan mudah diserap oleh lapisan usus, saluran udara, dan kulit. Agen ini, biasanya terkandung dalam spora jamur, memiliki efek toksik mulai dari iritasi jangka pendek - reaksi alergi, kurap, kudis - hingga pelemahan sistem kekebalan tubuh dan perdarahan paru (Quamila, 2020, para. 4).

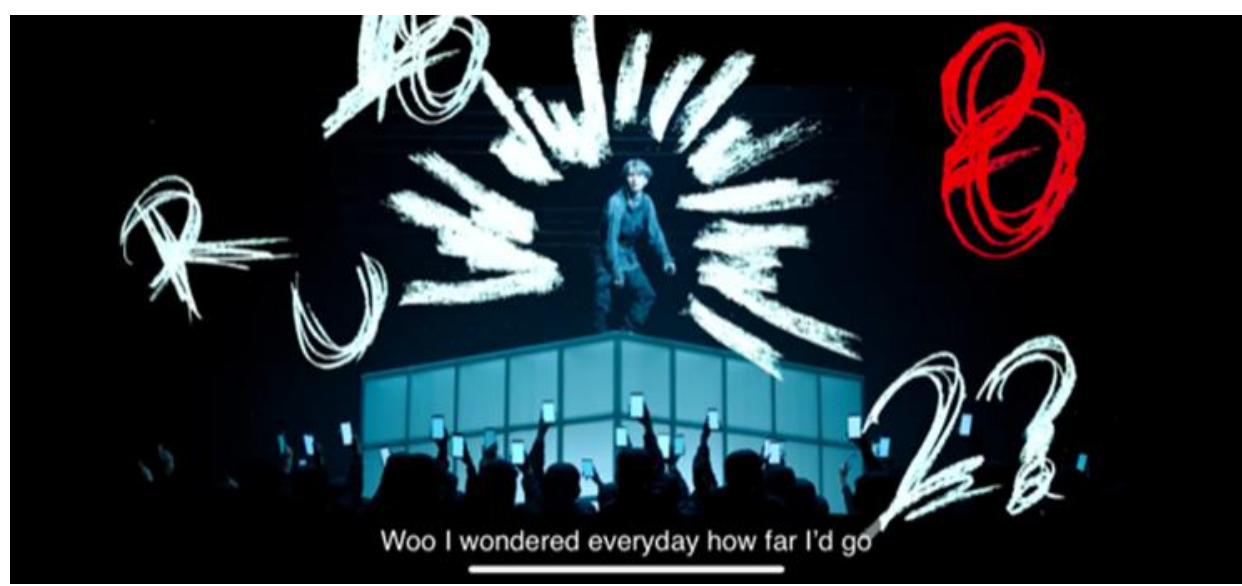

Gambar 2. Scene 2

Sumber: (akun Youtube Bighit Labels, 2020)

(Shoot: Long Shoot)

Suga: "I wondered everyday how far l'd go" 
Makna denotasi: Suga menyanyikan lirik "I wondered everyday how far l'd go" sambil berdiri di atas panggung dengan banyak penonton yang mengambil gambarnya (memotret) menggunakan ponsel.

Makna konotosi: Suga mulai merasa bingung terhadap kehidupannya dan bertanyatanya setiap harinya "seberapa jauh saya melangkah?". Maka "melangkah" di sini adalah langkah perjalanan kehidupan yang ia lalui, bagai mana ia bisa melalui kehidupannya sebagai seorang manusia biasa dan seorang idola. Terlihat juga bagaimana banyak orang-orang berjubah hitam yang terus menyorotinya dengan kamera ponsel, mencerminkan apa yang biasanya dilakukan para fans yang selalu mengerumuninya.

Mitos: seorang idola pasti pernah mengalami masa-masa terberatnya sehingga mereka bertanya-tanya pada diri mereka sendiri "apakah saya bisa melalui semua ini?". Kehidupan seorang idola sangatlah keras dengan masa depan yang tidak menentu. Dicintai sekaligus dibenci banyak orang, kenyataan seperti itulah yang membuat mereka kadang merasa memiliki harapan dan keputusasaan pada saat yang bersamaan. Terlebih lagi dengan sikap para fans yang kadang "brutal" dan cenderung melanggar privasi para idolanya.

Mengapa fans kerap kali melakukan aksi gila? Ada beberapa hal yang bisa menjadi alasan, seperti gangguan Celebrity Worship Syndrome atau sindrom pemujaan selebritas. Kondisi ini adalah gangguan obsesif-kecanduan di mana seseorang menjadi terlalu terlibat dan tertarik (benar-benar terobsesi) dengan rincian kehidupan pribadi seorang pesohor idolanya (sumber: Dhani, 2017, para. 13). Salah satu tindakan yang ekstrim adalah dengan mengerubungi idolanya saat di tempat umum dan berusaha mengambil foto melalui kamera atau posel, bahkan ada yang memaksa ingin menyentuh tubuh idolanya tersebut.

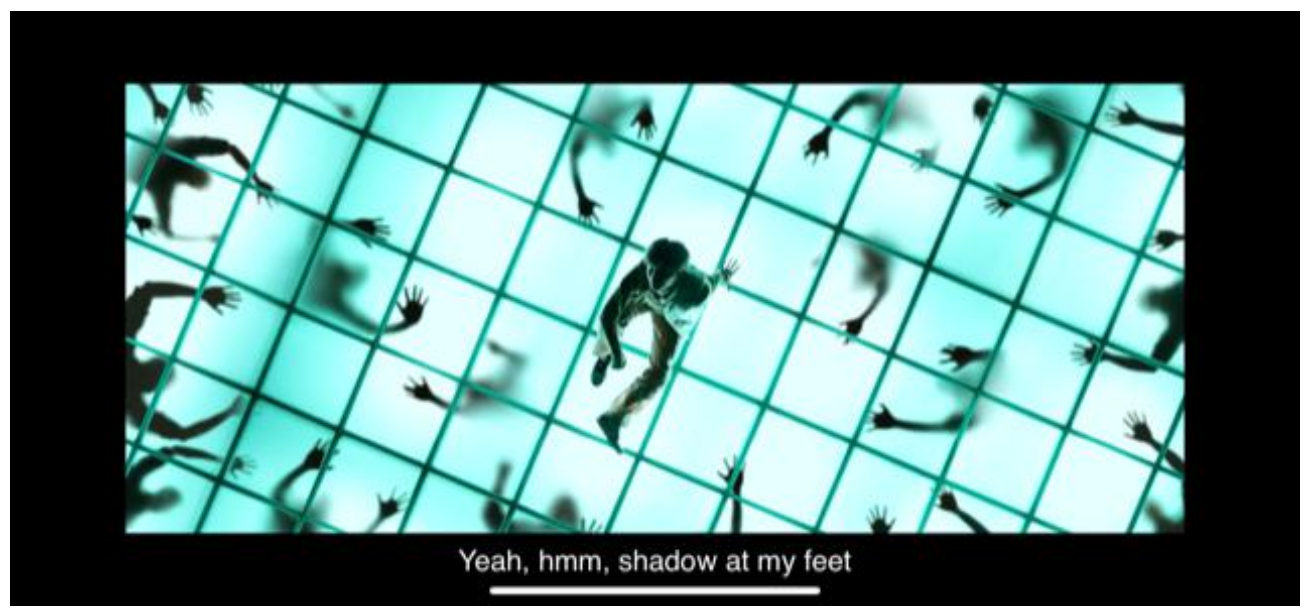

Gambar 3. Scene 3

Sumber: (akun Youtube Bighit Labels, 2020)

(Shoot: Long Shoot)

Suga: "Yeah, shadow at my feet"

Makna denotasi: Suga duduk di atas lantai kaca dengan banyak bayangan tangan hitam di balik lantai kaca tersebut yang seolah ingin menyentuhnya.

Makna konotasi: Suga duduk di atas lantai kaca dengan banyak bayangan tangan hitam di bawahnya yang seolah-lah bayangan hitam yang mencoba meraihnya itu adalah "bayangan" dari dirinya yang lain yang mencoba untuk "menelan" keberadaannya atau mereka itu adalah para pembenci yang berusaha ingin berada "di atas" seperti dirinya.

Mitos: bayangan yang mengikuti diri kita sendiri sifatnya bisa dikaitkan dengan sesuatu yang mistis, istilah ini disebut dengan "doppleganger". Doppelganger adalah istilah yang berasal dari bahasa jerman yang artinya Doppel ialah double dan Ganger yang berarti walker/goar. Dan istilah ini merujuk kepada bayangan yang menyerupai diri yang menyertai setiap manusia di bumi. Menurut kamus Mirriam - Webster, doppelganger memiliki empat karakteristik yaitu, ghost of a living person yang berarti hantu dari orang yang masih hidup, $A$ double yang berarti ganda, Alter ego yaitu kepribadian alternatif, A person who has the same 
name as the other yang berarti dua orang yang memiliki nama yang sama. Jadi dapat di simpulkan doppelganger ini ialah dua karakter yang tidak memiliki hubungan arat seperti saudara atau kembar. Tetapi memiliki karakter fisik dan sifat yang sama (Selidik, 2018, para. 34).

Jadi bisa dimaknai kalau bayangan-bayangan di kaki Suga tersebut adalah "alter ego" yang selalu mengikutinya. Bisa dimaknai pula kalau bayangan-bayangan itu adalah para haters (pembenci) yang berusaha untuk "meraih" dirinya. Para idol tidak akan luput dari yang Namanya haters, karena orang-orang yang tidak menyukai idola lain tersebut memang memiliki niat untuk menjatuhkan para idola atau artis yang tidak disukainya supaya tidak menyaingi artis idolanya tersebut.

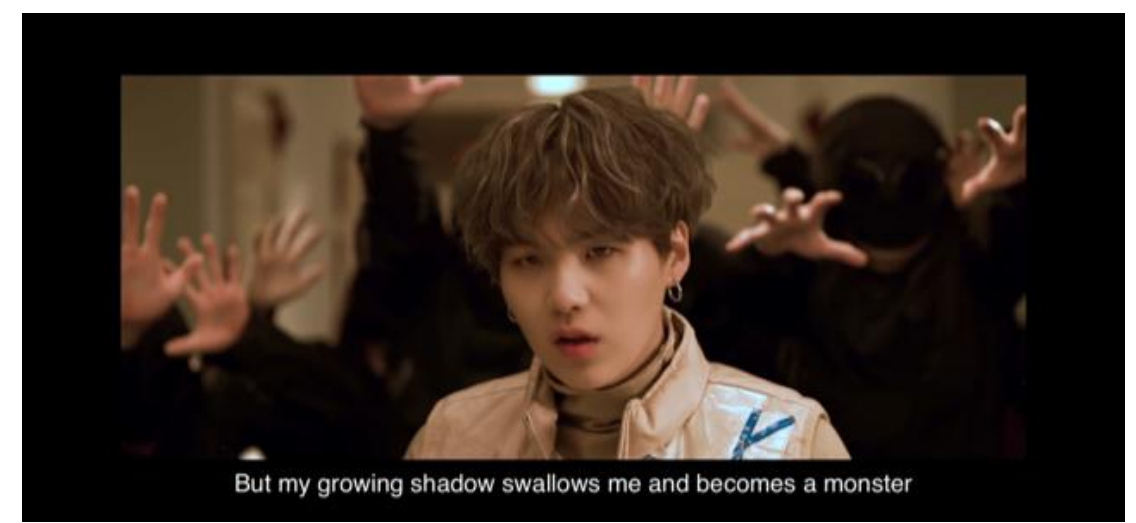

\section{Gambar 4. Scene 4}

Sumber: (akun Youtube Bighit Labels, 2020)

(Shoot: Close Up)

Suga: "But my growing shadow swallows me and becomes a monster"

Makna denotasi: Suga menyanyikan lirik "But my growing shadow swallows me and becomes a monster" dengan latar banyak tangan dari orang-orang berjubah hitam yang seolah mencoba untuk menyentuhnya.

Makna kontasi: "bayangan" yang dimaksud oleh si penyanyi di sini bisa jadi adalah doppleganger atau "alter ego" dirinya yang berusaha "menelan" jiwanya sehingga membuatnya menjadi seseorang yang buruk (dimaknai dari istilah "monster" alam lirik tersebut). Di mana bayangan yang digambarkan dengan tangan-tangan dari makhluk berjubah hitam ini yang berusaha untuk meraihnya.

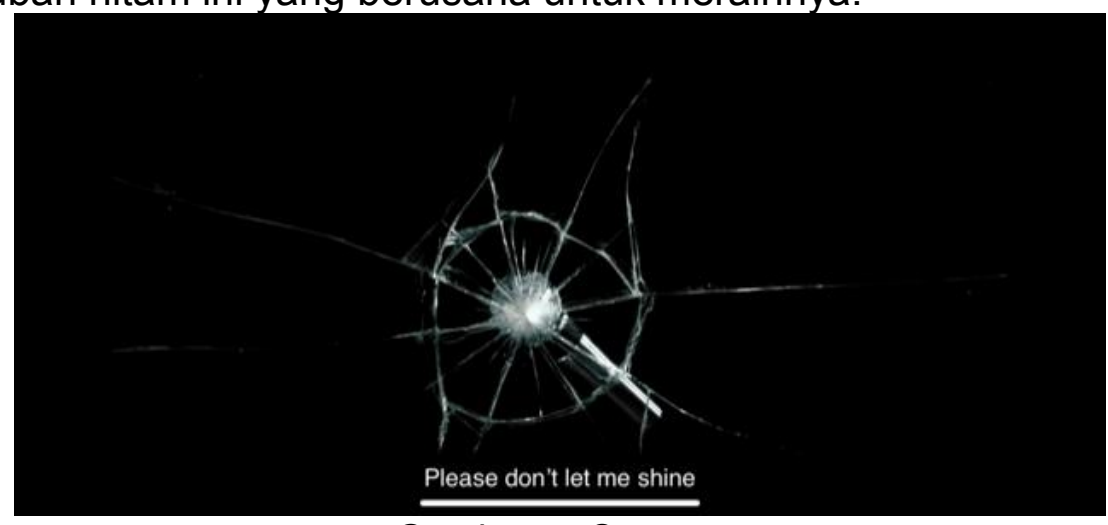

Gambar 5. Scene 5

Sumber: (akun Youtube Bighit Labels, 2020)

(Shoot: Close Up)

Suga: "Please don't let me shine"

Makna denotasi: digambarkan sebuah mic terjatuh di atas kaca sehingga membuat kaca tersebut menjadi pecah. 
Makna konotasi: dari lirik yang dinyanyikan oleh Suga "Please don't let me shine" seolah ia mengisyaratkan ketakutan dan keputusasaannya (hopelessness) dengan tidak ingin menjadi seseorang yang "bersinar" di lingkungannya.

Mitos: perasaan putus asa tak hanya terlihat dari lirik "Please don't let me shine" tersebut, tetapi juga dari visualisasi yang ditampilkan. Jatuhnya mic di atas kaca memberi makna "jatuhnya" keyakinan mereka para penyanyi dan musisi ke kondisi yang paling kelam, ditambah lagi dengan penggambaran kaca yang pecah. Berbeda dengan kepercayaan rakyat Eropa, negeri-negeri di Asia, terutama Tiongkok percaya bahwa kaca pecah tidak hanya dapat membawa sial di kehidupan ini, namun kehidupan berikutnya. Selain itu, mereka juga percaya bahwa bercermin pada kaca pecah dapat menjebak jiwa seorang manusia, membuatnya berkeliaran tanpa tanpa jati diri. Di Indonesia, mitos kaca pecah selalu disangkut-pautkan pada musibah yang akan melanda, entah itu pada keluarga, teman dekat, atau diri sendiri (Mahadi, 2019, para. 21).

Dengan jatuhnya mic di atas kaca yang menyebabkan hingga pecah tersebut dapat dimaknai sebagai sebuah musibah kelam yang akan terjadi pada si pemilik mic. Mic atau microphone itu sendiri merupakan properti penting yang harus dimiliki oleh seorang penyanyi, tanpa mic mereka seolah tidak bisa tampil di panggung tempat seharusnya mereka bekerja.

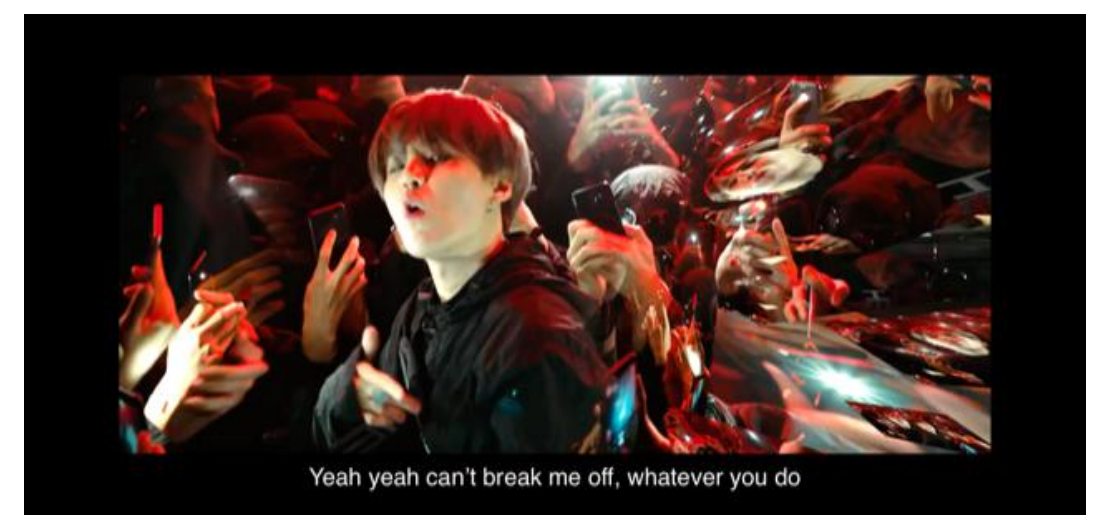

Gambar 6. Scene 6

Sumber: (akun Youtube Bighit Labels, 2020) (shoot: Medium Shoot)

Suga: "Yeah can't break me off, whatever you do"

Makna denotasi: banyak tangan orang-orang yang memegang kamera sambil berusaha untuk mengambil foto Suga. Sedangkan sang penyanyi nampak tidak bergeming sama sekali.

Makna konotasi: kalimat "Yeah can't break me off, whatever you do" dapat diartikan "kalian tidak bisa mematahkannku, apapun yang kalian lakukan". Makna dari "mematahkan" di sini adalah "mematahkan mimpi dan harapan", karena banyak orang-orang yang mecoba menjatuhkan para idolanya. Namun di scene ini, Suga tampak tidak bergeming seolah ia tidak peduli dengan orang-orang yang berusaha mematahkan harapan dan impiannya. Pemaknaan dari orang-orang yang berusaha mengambil foto tersebut adalaha para fans fanatik yang berusaha melanggar privasi para idolanya atau para awak media yang berusaha menguntit dan "mengganggu" kehidupan para artis.

Mitos: Menjadi selebriti, atau artis terkenal memang tidak selalu menyenangkan. Salah satunya adalah kurangnya privasi, dan susahnya menghadapi para fans. Terkadang karena saking terkenalnya, para artis yang sedang ingin melakukan quality time sendiri, atau dengan teman di tempat umum masih sering "diganggu" oleh fans mereka (rimma.co, 2017, para. 1). Seringkali pura mereka tidak mengetahui batas antara privasi dan pekerjaan dari sang idolanya itu sendiri. Mulai dari berusaha menyapa, mengambil foto dari jarak dekat hingga menyentuh, hal-hal tersebut dilakukan para penggemar yang mengarah kepada "fanatik".

Perilaku semacam ini seringkali dialami oleh banyak artis dn idola, salah satunya BTS. Salah satu momen yang paling tidak menyenangkan adalah saat bulan Juli 2018 silam, keberangkatan mereka di Bandara Incheon Korea Selatan menuju Taipei disambut oleh para 
fans yang mengerumuni dan mencoba untuk mendekat. Kelompok penggemar berlari mengejar grup dan memadati mereka dalam rekaman yang ditangkap oleh media dan penggemar. Pada satu titik seorang gadis muncul untuk mendorong ponselnya ke wajah BTS V, yang dia balas dengan mengeluarkan ponselnya sendiri dan pura-pura memfilmkannya dari dekat. Penggemar yang cerdik telah memperhatikan bahwa dia sebenarnya dalam mode selfie dan tidak menangkap rekaman apa pun dari dirinya, tetapi jelas mencoba untuk membuat "kode" tentang invasi ruang pribadinya (SBS Popasia HQ, 2018, para. 1-2). Saat kejadian serupa terulang lagi, para member BTS tidak pernah marah atau mengusir orang-orang tersebut, mereka memilih untuk diam dan tidak banyak bereaksi karena berusaha untuk tidak peduli.

\section{SIMPULAN}

Dari hasil analisa beberapa scene di video clip BTS Comeback Trailer 'Interlude: Shadow' menggunakan Semiotika Roland Bartes, ditemukan beberapa makna denotasi, konotasi dan mitos yang merujuk pada harapan dan hopelessness. Dari segi visualiasi dan lirik, si penyanyi yaitu Suga dapat dengan baik menuangkan emosi dan pemikirannya di video clip tersebut. Dapat dilihat dari scene 1 dan scene 6 yang menyiratkan akan harapannya pada kehidupan. Terdapat tiga komponen harapan yang saling terkait dalam definisi harapan yang dikembangkan Snyder, yaitu tujuan (goals), willpower, dan waypower. Tujuan merupakan suatu objek, pengalaman, atau hasil (outcome) yang dibayangkan dan diinginkan dalam pikiran kita, Willpower merupakan suatu kekuatan pendorong dalam berpikir penuh harapan (hopeful thinking), sedangkan Waypower menggambarkan rencana atau peta mental yang memandu pemikiran yang penuh harapan (hopeful thinking) (Hidayat, 2016, hal. 2).

Kalimat "I wanna be the top" dan "Yeah can't break me off, whatever you do", seolah Suga menyatakan bahwa ia selalu ingin berada di "atas", karir yang cemerlang dan menganggap bahwa orang-orang tidak bisa "manjatuhkannya" dalam keadaan apapun. Pada kalimat-kalimat tersebut pula ketiga aspek harapan telah ia lalui, mulai dari pengalamannya sebagai idola paling bergengsi di Korea Selatan saat ini, Soompi melaporkan, jumlah pre-order album saat ini sudah mencapai 4,02 juta copy, laporan itu berdasarkan pesanan yang masuk dan dicatat sama distributor resmi album BTS, Dreamus Company, per tanggal 17 Februari 2020. 'Map of the Soul: 7' pun makin mengukuhkan posisinya sebagai album K-Pop dengan jumlah pre-order terbanyak sepanjang sejarah (Pangaribuan, para. 2). Dengan segala kekuatan, kemampuan (willpower) dan juga rencana matang (waypower) untuk menciptakan karya-karya luar biasa yang diakui di seluruh dunia.

Dibalik pencapaiannya yang luar biasa, tak terelakan lagi bahwa kehidupan gemerlap para artis dan idola Korea Selatan sangat erat dengan perasaan depresi. Hal ini karena mereka dituntut untuk tampil sempurna di depan para fansnya, seakan tak boleh memiliki cela. Padahal artis maupun idola hanyalah manusia biasa yang punya perasaan, terkadang mereka juga mengalami masa-masa kelam. Hal ini ditunjukkan dari scene 2 dan 5, lirik berbunyi "I wondered everyday how far l'd go" dan "Please don't let me shine" seolah si penyanyi merasa bingung, putus asa dan kehilangan harapan.

Dengan visual yang menggambarkan banyaknya orang-orang yang berusaha untuk mengambil foto Suga dengan ponsel milik mereka dan juga mic terjatuh yang menyebkan kaca pecah, hal ini merepresentasikan bagaimana sulitnya hidup sebagai seorang idola yang selalu dikejar-kerja fans atau awak media yang berusaha melanggar privasi idola tersebut. Ditambah lagi dengan ketakutannya akan masa depan yang tiak pasti sebagai seorang musisi.

Pengertian Hopelessness atau keputusasaan diri adalah keadaan individu dengan kondisi lelah secara kognitif dan merasa putus asa. Hopelessness dapat disebabkan oleh beberapa faktor dan ditunjukkan dalam bentuk perilaku. Tentunya apabila seseorang mengalami hopelessness dan menunjukkannya dalam bentuk perilaku dipengaruhi serta mempengarruhi aspek lain dalam dirinya maupun lingkungan seseorang tersebut (Melinda \& Khusumadewi, 2017, hal. 52). Dari scene 2 dan 5 yang sudah dibahas di atas, hopelessness ini dapat timbul karena perasaan Lelah para idola dengan hilangnya privasi mereka dan "kegilaan" 
para awak media yang seakan "haus" ingin mencari tahu dan memberitakan kehidupan para selebriti. Ketakutan yang dirasakan oleh si penyanyi ia gambarkan dengan cara berlari menghindari orang-orang orang yang berusaha mengambil gambarnya tersebut. Sedangkan scene jatuhnya mic seakan merepresentasikan dari mitos kesialan akan timbul dari pecahnya kaca, seolah mengisyaratkan akan ada hal buruk yang akan harus dihadapinya di masa mendatang.

\section{DAFTAR PUSTAKA}

Bighit. (2020). About BTS. Sumber: https://ibighit.com/bts/eng/profile/

Dhani A. (2017). Penggemar K-pop Agresif?. Sumber: https://tirto.id/penggemar-k-pop-agresifcu6S (diakses pada 13 Februari 2020)

Gora, R. (2016). Representasi Perempuan Dalam Iklan Televisi (Studi Analisis Semiotika Iklan Beng-Beng Versi "Great Value"). Jurnal Universitas Bunda Mulia, 165.

Herman, T. (2018). BTS' UNICEF 'Love Myself' Campaign Raises Over \$1.4 Million. Sumber: https://www.billboard.com/articles/news/bts/8483029/bts-unicef-love-myself-campaignmoney-raised

Hidayat, A.S. (2016). Konstruksi Skala Harapan Remaja Berdasarkan Virtues In Actioninventory Of Strenghts. Repository Fakultas Psikologi Universitas Muhammadyah Malang, 2.

Kevin, N.A. (2019). Era BTS yang Positif dan Mendunia. Sumber: https://communication.binus.ac.id/2019/01/19/era-bts-yang-positif-dan-mendunia/

Kodri, M.A. (2016). Representasi Maskulinitas Boyband Shinee Dalam Video Klip Ring Ding Dong Melalui Ananlisis Semiotika. Jurnal Society Universitas Bangka Belitung, 54

Mahadi, S. (2019). Mitos Kaca Pecah: Apakah Benar Pembawa Sial? Begini Faktanya!. Sumber: http://www.99.co/blog/indonesia/mitos-kaca-pecah/

Mclntyre, H. (2020). Presales Of BTS's New Album Have Now Reportedly Passed 4 Million. Sumber: https://www.forbes.com/sites/hughmcintyre/2020/02/06/presales-of-btss-newalbum-have-now-reportedly-passed-4-million/\#2a45c1a64373

Melinda, R. dan Khusumadewi, A. (2017). Studi Perilaku Hopelessness Pada Siswa Di SMK Daruttaqwa, Gresik Study Of Student's Hopelessness Behavior In Daruttaqwa Vocational High School, Gresik. Junal BK Univeristas Negeri Surabaya, 52-53.

Pangaribuan, D. (2020). Raih 4 Juta Copy, Pre-Order Album Baru BTS Pecahkan Rekor. Sumber: $\quad$ https://www.mainmain.id/r/5410/raih-4-juta-copy-pre-order-album-baru-btspecahkan-rekor

Quamila, A. (2020). Awas! Dinding Rumah Berjamur Membahayakan Kesehatan Anda. Sumber: https://hellosehat.com/hidup-sehat/fakta-unik/risiko-kesehatan-rumah-berjamur-asmaalergi/

SBS PopAsia HQ. (2018). Fans defend BTS' V actions when bombarded by fans at airport. Sumber: $\quad$ https://www.sbs.com.au/popasia/blog/2018/07/09/fans-defend-bts-v-actionswhen-bombarded-fans-airport

Selidik. (2018). Doppelganger, bayangan yang menyerupai diri sendiri. Sumber: https://kumparan.com/creeps/doppelganger-bayangan-yang-menyerupai-diri-sendiri

Swastika. (2017). Pelajaran Berarti buat Para Fans Mengenai Pentingnya Privasi bagi Sang Idola. Sumber: https://www.rimma.co/55297/entertainment/pelajaran-berarti-buat-parafans-mengenai-pentingnya-privasi-bagi-sang-idola/

Wowkeren. (2019). BTS Punya Dampak Positif Terhadap Generasi Muda Menurut Para Tetua Korsel, Setuju?. Sumber: https://www.wowkeren.com/berita/tampil/00264573.html (diakses pada 8 Februari 2020) 